\title{
PDGFB Gene Mutation
}

National Cancer Institute

\section{Source}

National Cancer Institute. PDGFB Gene Mutation. NCI Thesaurus. Code C148122.

A change in the nucleotide sequence of the PDGFB gene. 